\title{
Pompiliu Teodor, 1930-2001
}

Pompiliu Teodor, who died on 7 September 2001, was a historian of enormous talent, a mentor of sympathetic understanding, and a colleague of infinite resources. Born in Ilia, in Hunedoara County, a largely Romanian region of southern Transylvania, on 19 July 1930, Teodor came from a family that had given the Orthodox Church generations of priests. But his father chose the civil service and politics and he himself the academy. Teodor received his bachelor's degree in history from the University of Cluj in 1954 and secured a position as researcher at the Library of the Romanian Academy in Cluj. Here he immersed himself in its rich holdings of manuscripts and other documents on the intellectual history of the Romanians of Transylvania in the eighteenth and the first half of the nineteenth century. In 1963 he moved to the University of Cluj as a lecturer and then as a professor of history. He obtained his doctorate in history in 1970 for his thesis about Samuil Micu, the theologian, historian, and linguist who was one of the leading figures of the Romanian Enlightenment. In 1990 he was elected a corresponding member of the Romanian Academy.

During the communist regime Teodor strove to maintain the integrity of the historical profession both in the classroom and in print. He opposed the use of history as a tool to satisfy the political and ideological goals of the moment, and he put himself on the side of those who, like the distinguished historian David Prodan, insisted that historical explanation be anchored in authoritative sources. He thus rejected both the rigid Marxist interpretation of Romania's historical development imposed by zealots in the early communist years and the exaggerated nationalism propagated later by the Ceausescu regime as it unraveled. Rather than adopt either of these extremes, he insisted that Romania's past could be made comprehensible only if it were studied from a broadly interdisciplinary and international perspective. His advocacy of regular intellectual contacts with other countries, especially western Europe and the United States, flowed from this conviction, and he continually sought opportunities for Romanian students to become directly acquainted with other cultures and to practice new approaches to the study of history. He himself taught and did research abroad, notably in Austria and Germany and in the United States as a Fulbright lecturer at the University of Illinois in 1972-1973.

After the collapse of the communist regime in 1989, Teodor played a key role in reorganizing the modern history program at the University of Cluj, broadening the conception of history and introducing new fields of study. On the national level he defended historians' right to present their opinions in the classroom and to the public without political interference. He founded two journals-Colloquia, a Journal of Central European History and Caietele David Prodan, which were designed to encourage research and publication on themes that had been neglected during the communist period. Perhaps his most ambitious undertaking was the creation of the Institute for Central European Studies at the University of Cluj in 1992, which sponsored new research and pioneering international conferences, especially on religious history and such delicate issues as the relations between the Orthodox and Greek Catholic churches.

Teodor's scholarly publications ranged widely over the modern history of the Romanians and of central Europe, and he also made significant contributions to the history of Romanian historiography in such works as Evoluția gândirii istorice româneşti (1970). But his favorite subject was the Enlightenment of the eighteenth century, in particular the responses of the Romanians of Transylvania to its incentives and challenges. He edited fundamental texts of leading Romanian figures, Samuil Micu and Gheorghe Sincai, and he wrote indispensable essays about them in Fragmentarium illuminist (1972) and in the masterpiece, Sub semnul luminilor: Samuil Micu (2000).

Teodor retired from the University of Cluj in 2000, but "retirement" hardly describes his subsequent activity. At Cluj he continued to supervise doctoral candidates and to serve as mentor to new as well as older generations of students, many of them now his colleagues. But he wanted to be in the classroom, and thus he assumed teaching duties at the

Slavic Review 61, no. 2 (Summer 2002) 
universities of Târgu Mureş and Alba Iulia. Numerous writing projects were also in the works, notably a new history of Romania.

It is hard to imagine being in Cluj and not meeting Pompiliu Teodor to exchange thoughts on everything imaginable, from the state of the profession and literature and philosophy to old and new politics and human foibles, and to try out good wine and Transylvanian cuisine. We had been doing it for forty years. He was interested in everything.

KeIth Hitchins University of Illinois, Urbana-Champaign November 2001

\section{John Albert White, 1910-2001}

Born in Providence, Rhode Island, on 14 August 1910, John Albert White died in League City, Texas, on 8 August 2001. White received his B.A. from the University of California, Los Angeles, in 1933, where he studied with Andrei Lobanov-Rostovsky; his M.A. from Columbia University under Geroid Tanquary Robinson in 1938; and his Ph.D. from Stanford University in 1947 under Harold Fisher. White's publications include The Siberian Intervention (1950), The Diplomacy of the Russo-Japanese War (1964), and Transition to Global Rivalry: Alliance Diplomacy and the Quadruple Entente, 1895-1907 (1995). While working at the Hoover Institution on his dissertation on the Siberian intervention, White obtained two research grants (1948 and 1949), and he was later awarded several Rockefeller Foundation research grants - to Japan in 1946-47 and again in 1954-55, and to England in 1963-64.

From 1947 to 1977 White was a professor of Russian history at the University of Hawai' i. He began his teaching career, however, with a focus on Asia that had been sparked by his having been sent to Colorado to study Japanese during World War II, and early in his career, he coauthored a book entitled Asia (1953) with the well-known historian Shunzo Sakamaki. During his time at the University of Hawai' $i$, White taught the general introduction to Russian history as well as specialized courses on Siberia and Central Asia, which he alternated every other year, and a course on Russian foreign policy. He served several times as chair of the department of history, actively participated in university committees, and lectured frequently in the community.

In 1960 White worked hard to persuade the newly created, federally funded East-West Center to include the Soviet Union within its ambit and was disappointed by his lack of success. Eventually, Russian scholars and students were able to receive scholarships and conference invitations, but only in the wake of glasnost and the collapse of the Soviet Union. But in 1986, almost a decade after White had retired, the University of Hawai' $i$ established a Center for the Soviet Union in the Asia Pacific Region. It was a real pleasure for him to see his lifetime interests recognized in such a formal way.

Another of White's biggest concerns was building up the library's collection on Russian history and, in particular, on Siberia. Over the years White worked tirelessly to persuade the library administration of the importance of continuing to build this collection.

We greatly miss the kindness and thoughtfulness of this gentlemanly professor.

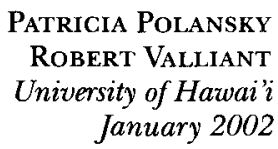

\section{George Barany, 1922-2001}

At the recent annual meeting held in Crystal City, Virginia, I was deeply aware of the ghosts in the halls, for some of the great figures in our profession are leaving us at an alarming rate. In my own field, Hungarian studies, we mourned Peter F. Sugar not that long ago, and now we mourn George Barany. His gaunt, lanky figure was a presence at most annual 